\title{
Music: A holistic approach to symptom management for patients undergoing cancer treatment
}

\author{
Jordan Roberts, Samantha Horn, Elizabeth Aquino, Kim Amer* \\ School of Nursing, College of Science and Health, DePaul University, Chicago, USA
}

Received: November 6, 2021

Accepted: January 16, 2022

Online Published: January 23, 2022

DOI: $10.5430 /$ jnep.v12n6p1

URL: https://doi.org/10.5430/jnep.v12n6p1

\begin{abstract}
Background and objective: Patients undergoing chemotherapy carry a tremendous amount of psychological and physical burdens. The focus of care in the oncology setting should include a blend of pharmacological and holistic medicine to achieve desired health goals. This research includes a comprehensive review of music therapy as a vehicle to promote psychotherapeutic effects on patients receiving chemotherapy. This review serves to identify the positive outcomes of patients engaging in music therapy while receiving chemotherapy.

Methods: An integrative literature review was conducted. Articles published between 2007 and 2020 were identified searching the databases of CINAHL, PubMed, and ProQuest. Key words included music therapy, psychological, chemotherapy, depression, anxiety and cancer.

Results: Eight articles were reviewed that identified three emotional effects in relation to receiving chemotherapy: anxiety, depression and quality of life. The literature focused on how music therapy was used to improve these emotional states. The Spielberger State Anxiety Inventory- State Anxiety Scale and other standardized units were used to evaluate the positive effects of music therapy. These tools, which help standardize assessments, found noticeable psychosocial improvements.

Conclusions: Further studies are needed to conduct a more comprehensive use of music therapy in the healthcare setting. Inclusive literature should also be available as an alternative method of treatment to provide additional outlets for improvement of health outcomes. The information studied has already found promising results of music therapy on patients' psychological wellbeing while receiving chemotherapy.
\end{abstract}

Key Words: Music therapy, Psychological, Chemotherapy, Depression, Anxiety and cancer

\section{INTRODUCTION}

Music can energize one's spirit, move one to tears, help one recall a simpler time or a past love, and music can heal one's soul. At one time or another, everyone has felt the mindaltering power of music. It is a tool that is often relegated to nonmedicinal purposes; however, the therapeutic properties of music have healed us all in various circumstances that we probably never even realized. The opposite can also be true-many people seek music as a remedy to lift a psycho- logical burden and as a balm for a wounded soul.

Music therapy, as a nursing intervention, embodies a holistic approach to nursing care. Music can take an individual to a place of healing, confidence, and peace. The science of music therapy includes individual and evidence-based music interventions to achieve goals set by the patient; this process uses both active and passive musical exercises. ${ }^{[1]}$ In the healthcare field, a therapeutic approach to treatment is a cornerstone of the healing process. And this therapeuUSA.

*Correspondence: Kim Amer; Email: kamer@ depaul.edu; Address: School of Nursing, College of Science and Health, DePaul University, Chicago, 
tic approach comes in many different facets, such as music therapy.

\subsection{Background \& significance}

According to the American Cancer Society, ${ }^{[2]}$ by the end of 2021 , there will be a projected 606,520 deaths from cancer and 1,806,950 new cases of cancer in the United States. Cancer is a devastating disease that affects the patient (and the family) in insurmountable ways. Galanis, Kalolairinou, Konstantakapoulou \& Spilioti ${ }^{[3]}$ state in their research that the physical, emotional, psychological, and financial burdens of cancer have a dramatic effect on the quality of life for the patient and the families involved.

\subsection{Historical perspectives}

Music therapy is not a new idea; music was used in Greek Mythology in many ways to illustrate an emotional effect on the listener. Orpheus used his music to convey his anguish and assuage his emotional pain, mourning his dead wife. ${ }^{[4]}$ Boethius influenced the world with music by penning these three types: instrumental, human and cosmic. He echoed Plato when he said that music has the power to affect an individual's mood and behavior. ${ }^{[5]}$ Shakespeare believed that man was comparable to a musical instrument that can be "out of tune" as well as "finely tuned". This idea communicates that harmonic proportions of music also infiltrate the physical body ${ }^{[6]}$ Gilliland ${ }^{[7]}$ reports in her original journal entry "The Healing Power of Music" that music therapy made huge advancements during the World Wars when it was prescribed for war neurosis, temporary insanity, other traumas of war and easing the mental discomfort of paralyzed muscles; music was also used to treat insomnia instead of prescribing medication.

\subsection{Current research}

Music therapy is currently used in a variety of modalities. These include singing, creating or composing music, listening to music or performing. The benefits of all modalities have been shared in current research. Quinn, Bodkin-Allen \& Swain ${ }^{[8]}$ identified overall positive benefits of music therapy, using group singing, for both patients and a control group. Gallagher et al. ${ }^{[9]}$ identified the benefits of patient and supportive family and friends singing. A computerized database was used in the evaluation. Wilcoxon signed rank test was used along with a paired $t$ test, before and after to see whether music therapy improved anxiety, body movement, facial expression, mood, pain, shortness of breath, and verbalizations. Sessions with family members identified that music therapy improved families' facial expressions, mood, and verbalizations. All benefits of the therapy were statistically significant $(p<.001)$. Most patients and families reported subjective and objective positive and beneficial responses to music therapy. A futuristic approach is described by Brungardt A, Wibben A, Tompkins AF, Shanbhag P, Coats H, LaGasse AB, Boeldt D, Youngwerth J, Kutner JS, Lum HD. ${ }^{[10]}$ They used virtual reality-based music therapy intervention with patient in palliative care to interpret the patient's compositions. Seventeen patients from ages 23-74 created their music sound track in a two day intervention then developed a 360 degree virtual reality experience that interpreted their music. The majority of participants reported positive feedback in addition to both emotional and physical responses to the virtual reality-based music therapy intervention. As illustrated in the background review of literature, music therapy is an excellent low cost intervention that should be considered when planning nursing care. Patients and families should be actively involved in the choice and modality.

Chia, Hsiu, Kuei, Mei, Ying, and Yuan ${ }^{[11]}$ conducted a metaanalysis on music interventions with cancer patients. The research yielded positive results as the patients involved reported improved quality of life, improved adjustments to pressures, pain relief, better able to express feelings, enhanced memory, improved communication, facilitated physiological rehabilitation, and achieved harmonic state of body, mind, and spirit. Their study used the Cochrane Collaboration Guidelines to ensure adequacy and quality of the studies conducted. Only studies with a 6 or more out of 10 were included in the meta-analysis. The findings confirmed that cancer patients who were experiencing pain and depression during their course of treatment can benefit from music therapy.

\subsection{Problem statement}

Music therapy is a holistic approach that can be used as a distraction and life enrichment during chemotherapy treatments, requiring little expense while improving patient outcomes Acaroglu and Bilgic. ${ }^{[12]}$ Much research has been concluded and many studies have been conducted to investigate the positive effects music therapy has on a patient receiving chemotherapy.

\subsection{Purpose of the study}

The purpose of this research is to explore the psychotherapeutic effects of music therapy on patients undergoing cancer treatment. The results of this research can be integrated into nursing interventions used to transform patient care. In addition, this study will include both Pamela Reed's theory of self-transcendence and Katherine Kolcaba's Comfort Theory as a focal point to reducing psychosocial effects of cancer. According to Ackerman, ${ }^{[13]}$ the main idea of selftranscendence is rising above oneself-relating one's values 
and beliefs to something greater. Music guides the patient to that transforming place of a higher perspective. Both cancer and treatments inflict incredible discomfort and anxiety to the patient; these undesirable feelings and side effects can negatively impact the patient and further worsen quality of life.

\subsection{Research question}

The following research question will be used to guide this literature review:

What are the psychotherapeutic effects of music therapy on patients undergoing cancer treatment?

\subsection{Conceptual theory and framework}

Patient comfort is one of the most important pillars of nursing. Katherine Kolcaba developed the Comfort Theory in 1990's, which is still relevant today. According to the Comfort Theory, comfort exists in three forms: relief, ease and transcendence. ${ }^{[14]}$ The Comfort Theory complements music as a holistic approach to medicine because it can be used as a medium to achieve each of the three forms mentioned above. Music relieves negativity, eases patient anxiety, and promotes patient self-transcendence. Transcendence is the "state of comfort in which patients are able to rise above their challenges.",[14]

Pamela Reed's Self-Transcendence theory (developed in 1991) can be applied to times of uncertainty and life-altering illnesses. People confronted with a diagnosis of cancer, facing the long road of chemotherapy, encounter many life changes. This life-changing circumstance confronts the patient and their family with new information, challenges, people, concerns, environments, and fears. Self-transcendence guides an individual to expand self-made boundaries in three areas: intra-personally (awareness of one's own philosophies, values and morals), interpersonally (relating to others and the environment) and trans-personally (broadened perspective about that which remains outside the individual's control). ${ }^{[15]}$ Focusing on connecting these areas will grant the individual access to inner peace and elevate them to a place of advanced perspective, fostered by well-being and vulnerability.

The model chosen to illustrate the purpose of this literature review incorporates facets of the Comfort Theory and Self-Transcendence. First, the patient's experience is the starting point which provides the need for the model. For this study, a patient suffering from cancer may experience emotional lability. Connecting with self, others, the environment etc. and evaluating one's own philosophies and values will aid the individual to find purpose with a more mature perspective of the situation. Second, emotional comfort comes from understanding one's own principles and estab- lishing healthy relationships. Finally, the journey to selftranscendence is not possible without patient participation. The patient must resolve to remain open to the possibilities of well-being through connection, support, and evaluation. Because music can modulate moods and emotions, it can then be used as a medium to guide the patient to a point of self-transcendence. ${ }^{[16]}$

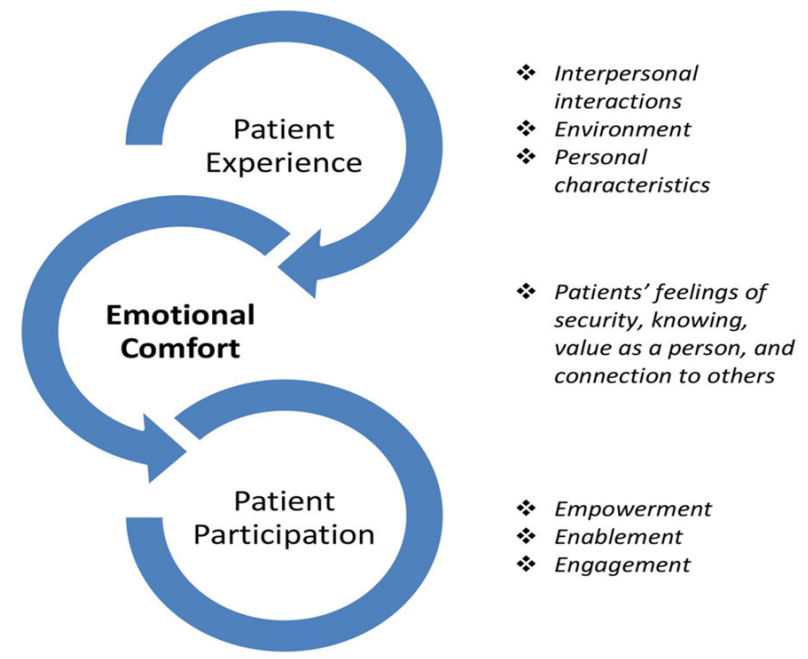

Figure 1. Kolcaba explanation of comfort theory

\section{MeTHODS}

\subsection{Research design}

This study was guided by Whittemore and Knafl's integrative literature review design to examine both the psychotherapeutic effects music therapy has on cancer patients and the strategies used as an intervention to improve outcomes in cancer patients. A variety of literature was utilized to determine how music therapy guides patients to achieve mental calmness in the fight through the disease process. The integrative literature reviews allow for multiple sources to be compared, analyzed, and critiqued based on the findings; this research diversity allows for a better understanding and evaluation of whether or not music therapy has a beneficial effect on cancer patients during treatment.

\subsection{Literature search strategy}

The following databases were searched for this integrative literature review: CINAHL, PubMed and ProQuest. Key words searched included: music therapy, psychological, chemotherapy, depression, anxiety and cancer. Article inclusion criteria included:

- Population of patients who were receiving chemotherapy as treatment while using music therapy as adjunct therapy

- Articles that were published between 2007-2020

- Documentation of improved psychological effects on patient's wellbeing and improved outcomes 
- Duration of music therapy and type of music played during the session

The research produced a total of 119 articles. Of the 119 articles found, 8 articles met the criteria needed and were chosen for a more thorough review (see Figure 2).
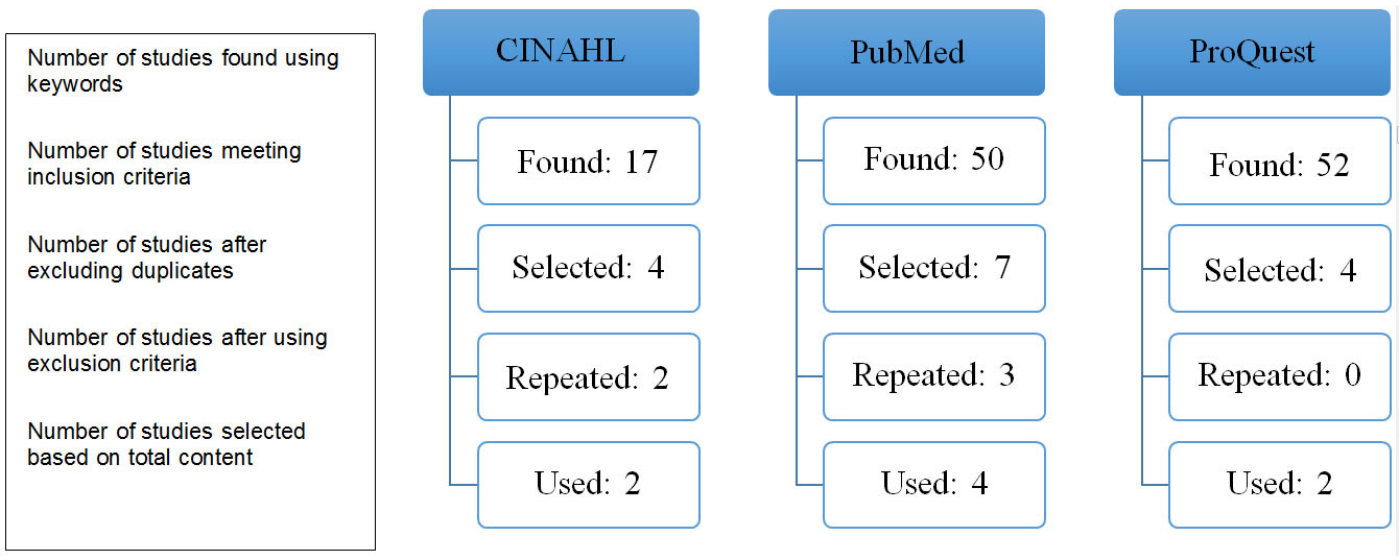

Figure 2. Literature search and results on psychological effects of music therapy

\subsection{Data synthesis \& analysis}

A total of eight articles were reviewed. The findings were assembled into a data matrix table displaying the author, publication date, purpose, sample, design study, results, and limitations of the articles (see Table 1). When selecting articles, the content pertained specifically to cancer patients undergoing chemotherapy. The articles showed various positive psychological effects due to music therapy, thus, narrowing the specific psychological effects studied that successfully influenced patients during chemotherapy.

\section{Results}

A patient fighting cancer undoubtedly suffers a tremendous amount of physical and psychological pain. Bradt, Dileo, Magill, \& Teague ${ }^{[17]}$ investigated effects of music therapy and medicinal interventions of both the psychological and physical outcomes in people with cancer; they found that mental health and physical health complement each other. Therefore, when healthy mental habits are established, physical health outcomes should improve as well. Krishnaswamy and Nair ${ }^{[18]}$ advocate for the need of nonpharmacological approaches to reducing anxiety and pain in patients enduring chemotherapy treatments. Acaraglu and Bilgic ${ }^{[12]}$ found that music helped reduce the symptoms of chemotherapy and increased the comfort level of patients post treatment. Mahon and Mahon ${ }^{[1]}$ conducted a research study that yielded positive results through both active and passive participation in music therapy sessions with a duration of at least thirty minutes. Aazami, Jasemi \& Zabihi ${ }^{[19]}$ found that patients reported feelings of less anxiety and depression after music therapy sessions. They also concluded that music therapy proved to be an inexpensive, non-invasive method to decrease 4 the amount of anxiety and depression experienced by patients suffering from cancer. Galanis et al. ${ }^{[3]}$ reported that patients felt less stress and anxiety after a music therapy session. Not only listening to music, but also participating in playing an instrument or singing reduced anxiety and depression, which are exercises that can be done without the music therapist. ${ }^{[1]}$

Along with the strong evidence that supports the fact that music therapy has a positive effect on patient status during chemotherapy, patient participation is at the center of having a positive outcome; those who did not want music therapy showed no significant improvement of mood. ${ }^{[21]}$ Out of the eight articles that were reviewed, three main psychological impacts were found in relationship to music therapy: anxiety, depression, and quality of life.

Music Therapy and Anxiety. Anxiety was one of the main psychological factors observed among patients due to the anticipation of chemotherapy. According to Bradt et al., ${ }^{[18]}$ the majority of patients reported anxiety leading up to and during chemotherapy. After implementing music therapy prior to and during chemotherapy sessions, patients reported the benefits of music therapy as well as readiness to explore other emotions related to chemotherapy. Lin, Hsieh, Hsu, Fetzer, \& $\mathrm{Hsu}^{[21]}$ conducted a study of two patient groups with high state anxiety due to receiving chemotherapy; one group participated in thirty minutes of music therapy while the other group did not. The participants who listened to thirty minutes of music reported a significant reduction in feelings of anxiety while the other group reported no change in anxiety. The result was determined by using a series of anxiety scales such as Spielberger State Anxiety InventoryState Anxiety Scale and other standardized units.

ISSN 1925-4040 E-ISSN 1925-4059 
Table 1. Data display of articles

\begin{tabular}{|c|c|c|c|c|c|}
\hline Source & Purpose & Sample & Method & $\begin{array}{l}\text { Results/Variable of } \\
\text { Interest }\end{array}$ & Limitations \\
\hline $\begin{array}{l}\text { Bradt J, Dileo C, } \\
\text { Magill L, Teague A. } \\
(2016)\end{array}$ & $\begin{array}{l}\text { To assess and compare } \\
\text { the effects of music } \\
\text { therapy for } \\
\text { psychological and } \\
\text { physiological outcomes } \\
\text { with patients with } \\
\text { cancer. }\end{array}$ & $\begin{array}{l}\mathrm{N}=3731 \\
\text { Both adult and } \\
\text { pediatric patients } \\
\text { were evaluated. } \\
\text { Each participant } \\
\text { listened to } \\
\text { pre-recorded music. }\end{array}$ & $\begin{array}{l}\text { Post-test scores that } \\
\text { evaluated anxiety } \\
\text { levels using the } \\
\text { Spielberger State } \\
\text { Anxiety Inventory } \\
\text { Scale. }\end{array}$ & $\begin{array}{l}\text { Music intervention has } \\
\text { beneficial effects on } \\
\text { anxiety, pain, fatigue, } \\
\text { and quality of life. }\end{array}$ & $\begin{array}{l}\text { Most trials were } \\
\text { high risk of bias } \\
\text { and need to be } \\
\text { interpreted with } \\
\text { caution }\end{array}$ \\
\hline $\begin{array}{l}\text { Bradt J, Potvin N, } \\
\text { Kesslick A, et al. } \\
(2014)\end{array}$ & $\begin{array}{l}\text { To compare the impact } \\
\text { of music therapy (MT) } \\
\text { versus music medicine } \\
\text { (MM) interventions on } \\
\text { psychological outcomes } \\
\text { and pain in cancer } \\
\text { patients and to enhance } \\
\text { understanding of } \\
\text { patients' experiences of } \\
\text { these two types of music } \\
\text { interventions. }\end{array}$ & $\begin{array}{l}\mathrm{N}=31 \\
\text { Adult population was } \\
\text { evaluated. } \\
\text { Two sessions were } \\
\text { evaluated by listening } \\
\text { to pre-recorded music } \\
\text { with a music } \\
\text { therapist. Before and } \\
\text { after each session } \\
\text { patient reported their } \\
\text { mood, anxiety, pain, } \\
\text { and relaxation. }\end{array}$ & $\begin{array}{l}\text { Mixed methods } \\
\text { intervention design in } \\
\text { which qualitative data } \\
\text { were embedded within } \\
\text { a randomized } \\
\text { cross-over trial. }\end{array}$ & $\begin{array}{l}\text { The qualitative data } \\
\text { indicate that music } \\
\text { improves symptom } \\
\text { management, } \\
\text { embodies hope for } \\
\text { survival, and helps } \\
\text { connect to a pre-illness } \\
\text { self, but may also } \\
\text { access memories of } \\
\text { loss and trauma. }\end{array}$ & $\begin{array}{l}\text { Both music } \\
\text { therapy and } \\
\text { music medicine } \\
\text { were both } \\
\text { effective on } \\
\text { patient's } \\
\text { psychological } \\
\text { state. }\end{array}$ \\
\hline $\begin{array}{l}\text { Ferrer \& Alejandra } \\
(2007)\end{array}$ & $\begin{array}{l}\text { The Purpose of the study } \\
\text { was to investigate the } \\
\text { effects of familiar live } \\
\text { music on anxiety levels } \\
\text { of patients undergoing } \\
\text { chemotherapy as } \\
\text { treatment. }\end{array}$ & $\begin{array}{l}\mathrm{N}=50 \\
\text { Randomly selected } \\
\text { patients listened to } \\
\text { familiar live music } \\
\text { during chemotherapy } \\
\text { treatment. }\end{array}$ & $\begin{array}{l}\text { Quantitative Pre and } \\
\text { Post questionnaire } \\
\text { Patient listened to } \\
\text { music of choice } 20 \\
\text { minutes during } \\
\text { chemotherapy }\end{array}$ & $\begin{array}{l}\text { Results of the study } \\
\text { showed statistically } \\
\text { significant } \\
\text { improvement for the } \\
\text { experimental group on } \\
\text { the measures of } \\
\text { anxiety, fear, fatigue, } \\
\text { relaxation, and } \\
\text { diastolic blood } \\
\text { pressure }\end{array}$ & $\begin{array}{l}\text { A greater } \\
\text { population } \\
\text { undergoing } \\
\text { chemotherapy } \\
\text { treatment is } \\
\text { needed. }\end{array}$ \\
\hline $\begin{array}{l}\text { Lin, M., Hsieh, Y., } \\
\text { Hsu, Y., Fetzer, S., } \\
\text { \& Hsu, M. (2011) }\end{array}$ & $\begin{array}{l}\text { To determine the effect } \\
\text { of music therapy on } \\
\text { anxiety and anxiety } \\
\text { induced physiological } \\
\text { manifestation among } \\
\text { chemotherapy patients }\end{array}$ & $\begin{array}{l}\mathrm{N}=98 \\
\text { Listened to one hour } \\
\text { of single music } \\
\text { session and then were } \\
\text { evaluated using the } \\
\text { Spielberger } \\
\text { State-Trait Anxiety } \\
\text { Tool. }\end{array}$ & $\begin{array}{l}\text { Randomized control } \\
\text { trial and permuted } \\
\text { block design were } \\
\text { used. One hour of } \\
\text { music session and } 30 \\
\text { minutes of relaxation. }\end{array}$ & $\begin{array}{l}\text { Music therapy had a } \\
\text { greater positive effect } \\
\text { on post-chemotherapy } \\
\text { anxiety }\end{array}$ & $\begin{array}{l}\text { The type of } \\
\text { music that was } \\
\text { used was not } \\
\text { listed. }\end{array}$ \\
\hline $\begin{array}{l}\text { Pothoulaki, M., } \\
\text { MacDonald, R., \& } \\
\text { Flowers, P. (2012) }\end{array}$ & $\begin{array}{l}\text { To explore the } \\
\text { psychological processes } \\
\text { involved with } \\
\text { improvisational music } \\
\text { therapy for cancer } \\
\text { patients. }\end{array}$ & $\begin{array}{l}\mathrm{N}=9 \\
\text { The } 9 \text { participants } \\
\text { listened to } \\
\text { improvisational } \\
\text { music therapy }\end{array}$ & $\begin{array}{l}\text { Music therapy } \\
\text { program and semi- } \\
\text { structured interviews. } \\
\text { Interpretative } \\
\text { phenomenological } \\
\text { analysis was } \\
\text { conducted to explore } \\
\text { the methodologic } \\
\text { framework of the } \\
\text { interviews. }\end{array}$ & $\begin{array}{l}\text { Peer support and group } \\
\text { interaction, increased } \\
\text { self-confidence, } \\
\text { relaxation and overall } \\
\text { feeling of positivity } \\
\text { were obtained with } \\
\text { music therapy. }\end{array}$ & $\begin{array}{l}\text { One of the } \\
\text { participants } \\
\text { dropped out of } \\
\text { the study due to } \\
\text { hearing } \\
\text { impairment. The } \\
\text { study was } \\
\text { evaluated on all } \\
\text { end-stage cancer } \\
\text { patients. }\end{array}$ \\
\hline $\begin{array}{l}\text { Şebnem Bilgiç1 and } \\
\text { Rengin Acaroğlu2 } \\
\text { (2017) }\end{array}$ & $\begin{array}{l}\text { Does listening to music } \\
\text { effectively reduce the } \\
\text { severity of chemotherapy } \\
\text { symptoms and enhance } \\
\text { the comfort of patient } \\
\text { receiving chemo }\end{array}$ & $\begin{array}{l}\mathrm{N}=70 \\
\text { Outpatient } \\
\text { chemotherapy } \\
\text { patients listened to } \\
\text { music using } \\
\text { headphones to listen. }\end{array}$ & $\begin{array}{l}\text { A quasi-experimental } \\
\text { two-group pre-test and } \\
\text { post-test design }\end{array}$ & $\begin{array}{l}\text { Results confirmed that } \\
\text { listening to music } \\
\text { diminishes the severity } \\
\text { of symptoms patients } \\
\text { receiving } \\
\text { chemotherapy and } \\
\text { improved their overall } \\
\text { comfort levels. As well } \\
\text { as, improved overall } \\
\text { quality of life } \\
\end{array}$ & $\begin{array}{l}\text { Further research } \\
\text { should be done } \\
\text { over longer } \\
\text { study period }\end{array}$ \\
\hline $\begin{array}{l}\text { Warth, M., Keßler, } \\
\text { J., Hillecke, T. K., \& } \\
\text { Bardenheuer, H. J. } \\
(2015)\end{array}$ & $\begin{array}{l}\text { Music therapy efficacy } \\
\text { of music therapy as } \\
\text { palliative care in } \\
\text { terminally ill patients }\end{array}$ & $\begin{array}{l}\mathrm{N}=84 \\
\text { Hospitalized patients } \\
\text { in palliative care were } \\
\text { assigned one of two } \\
\text { treatments; live music } \\
\text { or listening to verbal } \\
\text { relaxation. }\end{array}$ & $\begin{array}{l}\text { Randomized } \\
\text { controlled trial }\end{array}$ & $\begin{array}{l}\text { Music therapy had a } \\
\text { low dropout rate and } \\
\text { had a positive effect on } \\
\text { relaxation and } \\
\text { well-being on } \\
\text { terminally ill patients. }\end{array}$ & $\begin{array}{l}\text { Cancer patients } \\
\text { were not the } \\
\text { only patients } \\
\text { being studied. } \\
\text { This study } \\
\text { included other } \\
\text { terminally ill } \\
\text { patients as well. }\end{array}$ \\
\hline
\end{tabular}


Music helped in two ways: first, it took them to a place of tranquility; second, music helped them temporarily forget their current stressors. ${ }^{[20]}$ Reed's theory of selftranscendence and Kolcaba's Comfort Theory play an integral part in achieving anxiety relief amidst the perils of cancer. The patient's emotional comfort must be kept at the center. This desired feeling is influenced by the patient's experiences as well as their participation in achieving wellness. In this case, cancer is the experience and music therapy is the participation-both working together to create a space of comfort.

Music Therapy and Depression. Of the eight articles reviewed, depression was another psychological phenomenon that occurred in patients undergoing cancer treatment. Bradt, Dileo, Magill, \& Teague $^{[18]}$ found that music therapy had a positive impact on patients experiencing depression as a result of chemotherapy. When patients received music therapy as adjunct treatment, they reported feelings of relaxation and a boost in mood. As seen above, participation is imperative to achieving the desired outcome of self-transcendence and the Comfort Theory. Acaroglu \& Bilgic ${ }^{[12]}$ determined from their study that patients showed a significant decrease in depressed mood (among other psychological effects) after listening to preferred music for thirty minutes three to four times a week.

Music Therapy and Quality of life. Quality of life is evaluated through a person's self-reflection on satisfaction, emotional state, and feeling of purpose. Warth, Keßler, Hillecke, $\&$ Bardenheuer ${ }^{[22]}$ observed patients reporting a greater reduction in fatigue resulting in an improvement on the quality of life scale. It should also be noted that a reduction in anxiety and depression (among other negative emotions) will elevate the patient's experience and ultimately better their quality of life. The improvement of all of these emotions works together towards a common goal of desired patient outcomes. These outcomes are illustrated by implementing the components from the theories of self-transcendence and the Comfort Theory. The result of patient participation despite their circumstances will blossom into feelings of relief, ease and emotional freeness. Music therapy has been proven to be an effective adjunct treatment in improving the quality of life in patients who are receiving chemotherapy.

\section{Discussion}

The purpose of this integrative literature review was to determine the psychotherapeutic benefits of music therapy to help a patient cope with cancer. Three major psychological effects were positively impacted by music therapy: anxiety, depression and quality of life. These psychological effects were all improved with the utilization of music therapy, anxi- ety showing the greatest improvement. Decreasing anxiety prior to and during chemotherapy improves patient outcomes, decreases depression and improves quality of life. ${ }^{[12]}$ While music therapy is the medium to drive a patient towards emotional wellness, the principles of the theories mentioned in this study work together to achieve that desired result. One complements the other. In other words, Reed's selftranscendence theory is the intangible result from the active implementation of Kolcaba's Comfort Theory through the influence and science of music therapy.

A variety of music therapy strategies were used to help identify the most beneficial ways to improve mood during cancer treatment. These strategies include playing instruments, singing songs, composing or listening to music. Most sessions reviewed in the literature included thirty minutes of therapy where patients reported improved mood and calmness.

Music therapy has a positive psychotherapeutic effect on patients undergoing cancer treatment. It is a holistic approach to decreasing anxiety and depression, and increasing quality of life by providing an outlet for patients to express themselves while offering a safe and economical addition to traditional treatment. This alternative therapy will also strengthen relationships between music therapist, nurse and patient to foster the desired goal of healthy outcomes. The qualitative benefit of music therapy is illustrated in the following case study.

\subsection{Case study}

Mary battled cancer for many years and departed a husband and four kids. She loved butterflies and spent her days building wooden houses when she wasn't too weak from chemotherapy. Working with a music therapist, Mary began to write a song about butterflies with undertones of healing and restoration. She was enthralled by the transformational process of a caterpillar becoming a butterfly, so she wrote about this miraculous transfiguration. This conversion, for Mary, symbolized change and forgiveness-something she battled with deeply. Mary not only dealt with the paralyzing diagnosis of cancer but also with the horrors of past abuse. Her musical composition fostered reconciliation and comfort in the darkest of moments. For Mary, music connected a broken family and provided healing to her wounded soul. ${ }^{[23]}$

The above case study illustrates the model of selftranscendence and the ability of the patient to be open to connecting with the music therapist. The creation of music provided unexpected benefits with integration of images that helped her cope with both her past abuse and her present challenge of coping with cancer. In the case Mary experiences self-transcendence, a state of mind that moves the person 
beyond their earthly troubles and inspires a spiritual sense of well being and peace.

\subsection{Limitations}

Music therapy is an individualistic method of treatment because music is a personal expression of art and interpretation. One style of music does not break barriers for all patients; therefore, it is imperative to cater to the patient's musical preferences in order to see the desired effects of music therapy. In many studies, patients did not pick their preferred musical style, which greatly reduced the impact of music therapy. The music therapist or healthcare provider must remain open and flexible to adapt the fundamentals of music therapy to the needs of each patient. Also, the patients who were studied suffered from different cancers and were in different stages of cancer. This variability has a major impact on mood and participation.

\subsection{Suggestions for future research}

Patient outcomes vary depending on duration of therapy, preferred music genre and strategy. The exact mechanism of the complex psychological and physical responses to music therapy has not been studied thoroughly; while the understanding of how music therapy works is still unknown, research points towards a positive psychological effect with minimal physical changes. ${ }^{[3]}$ Comprehensive research needs to be conducted to establish a more wide-range use of music therapy in the healthcare setting. Inclusive literature needs to be available for use as an alternative method of treatment to provide additional outlets for improvement of health outcomes. The proposed idea will equip healthcare professionals with effective ways to care for cancer patients. More research yielding definitive answers will play a revolutionary role in patient care, especially as a practice that is easily accessible to practitioners and patients alike.

\subsection{Implications for nursing}

Music therapy should become a common nursing intervention to assuage the discomforts associated with chemotherapy treatment in their patients. Music therapy is an underutilized, effective form of holistic treatment. It serves as a healing balm, carrying the weight of human suffering under the most burdensome circumstances and paving the way toward emotional wellness, regardless of the prognosis. Ultimately, more education and resources need to be provided for healthcare professionals so that they are aware of the effectiveness of music therapy during courses of chemotherapy treatment. In addition, more hospitals need to understand the importance of establishing music therapy programs which will enhance patient health outcomes. Patients should also be involved in selecting the type of music utilized for music therapy.

\section{Conclusion}

This integrative literature review has provided a preliminary comprehensive study of the psychotherapeutics effects used in music therapy to improve health outcomes in patients undergoing cancer treatment. The research has identified positive results of music as a holistic approach to emotional wellness. More research needs to be formulated, but the information already found shows promising results.

No patient should feel uncomfortable or uneasy in the healthcare setting; no one enjoys going to the emergency department, staying at the hospital, or-much worse-spending time in an oncology unit. The reality, though, is that patient comfort gets lost in the wake of treatment practices and routine busyness. Part of providing excellent care includes ensuring the care environment is inviting and welcoming so that patients feel at home away from home. This model is often difficult to maintain, but more can be done to ensure patient comfort.

Oncology units that incorporate best evidence-based practices to support zen and solace for their patients should include music therapy. Music holds the power (to transform moods and enrich a weary soul) to shine a light in the darkest of times and carry the heaviest burdens. It is a clinical pearl that every patient should benefit from. Could music therapy be the key that unlocks a new realm of discovery that enhances patient experience throughout the course of chemotherapy treatment?

\section{CONFLicts OF INTEREST Disclosure}

The authors declare that there is no conflict of interest.

\section{REFERENCES}

[1] Mahon EM, Mahon SM. Music Therapy: A Valuable Adjunct in the Oncology Setting. Clinical Journal of Oncology Nursing. 2011; 15(4): 353-356. PMid:21810567 https ://doi.org/10.1188/11 . CJON. 353-356

[2] American Cancer Society. American Cancer Society: CanPublished by Sciedu Press cer Facts \& Statistics. 2020. Available from: https: //cancerstatisticscenter. cancer .org/?_ga=2 .1010014 9.1033338230.1593010382-1354110921.1593010382\#! /

[3] Galanis P, Kalolairinou AG, Konstantakapoulou OK, et al. The Effects of Music on Cancer Patients Submitted to Chemotherapy Treatment. International Journal of Caring Sciences. 2017; 10(3): 1465- 
1477. https://doi.org/10.1093/0195134079.001.0001

[4] Greeka. Orpheus and Eurydice. Greeka. 2019. Available from: https ://www.greeka.com/greece-myths/orpheus-euryd ice.htm

[5] Marenbon J. Boethius. Oxford: Oxford University Press; 2003. https://doi.org/10.1093/0195134079.001.0001

[6] Williams AM, Lester L, Bulsara C, et al. Patient Evaluation of Emotional Comfort Experienced (PEECE): Developing and testing a measurement instrument. BMJ Open. 2017; 7(1). PMid:28122833 https://doi.org/10.1136/bmjopen-2016-012999

[7] Gilliland EG. The Healing Power of Music. Music Educators Journal. 1944; 31(1): 18-20. https://doi.org/10.2307/3386692

[8] Quinn C, Bodkin-Allen S, Swain N. Group singing improves both physical and psychological well-being in people with and without chronic health conditions:Anarrativereview. Journal of Health Psychology. 2021. https://doi-org.ezproxy.depaul.edu/10.1 $177 / 13591053211012778$

[9] Gallagher LM, Lagman R, Walsh D, et al. The ClinicalEffects of Music Therapy in Palliative Medicine Supportive Care in Cancer. 2006; 859-866. PMid:16538499 https://doi.org/10.1007/s0 0520-005-0013-6

[10] Brungardt A, Wibben A, Tompkins AF, et al. Virtual RealityBased Music Therapy in Palliative Care: A Pilot Implementation Trial. J Palliat Med. 2021; 24(5): 736-742. PMid:33227225 https://doi.org/10.1089/jpm.2020.0403

[11] Chia C, Hsiu F, Kuei R, et al. Effectiveness of Music Intervention in Ameliorating Cancer Patients' Anxiety, Depression, Pain and Fatigue A meta-analysis review Cancer Nursing. 2014.

[12] Bilgiç Ş, Acaroğlu R. Effects of listening to music on the comfort of chemotherapy patients. Western Journal of Nursing Research. 2016; 39(6): 745-762. PMid:27515501 https://doi.org/10.1177/01 93945916660527

[13] Ackerman C. What is Self-Transcendence? Definition and 6 Examples (PDF). 2020. Available from: https://positivepsycholo gy.com/self-transcendence/
[14] Kolcaba K. Comfort Theory and Practice: A Vision for Holistic Health Care and Research. Springer Publishing Company Inc. New York. Print. 2003.

[15] Smith MJ, Liehr PR. (Eds.). Middle range theory for nursing: Third edition. 2013. Available from: https://ebookcentral.proques t. com

[16] Craig H. What is Music Therapy and How Does It Work? 2020. Available from: https://positivepsychology.com/music-t herapy/

[17] Bradt J, Dileo C, Magill L, et al. Music interventions for improving psychological and physical outcomes in cancer patients. The Cochrane Database of Systematic Reviews. 2016; (8): CD006911. PMid:27524661 https://doi.org/10.1002/14651858.CD006 911 . pub3

[18] Krishnaswamy P, Nair S. Effect of music therapy on pain and anxiety levels of cancer patients: A pilot study. Indian Journal of Palliative Care. 2016; 22(3): 307. PMid:27559260 https ://doi .org/10.4 103/0973-1075. 185042

[19] Zabihi R, Jasemi M, Aazami S. The effects of music therapy on anxiety and depression of cancer patients. Indian Journal of Palliative Care. 2016; 22(4): 455. PMid:27803568 https : //doi .org/10.4 103/0973-1075.191823

[20] Ferrer AJ. The Effect of Live Music on Decreasing Anxiety in Patients Undergoing Chemotherapy Treatment. Journal of Music Therapy. 2007; 44(3): 242-255. PMid:17645387 https ://doi .org/10 $.1093 / \mathrm{jmt} / 44.3 .242$

[21] Lin M, Hsieh Y, Hsu Y, et al. A randomised controlled trial of the effect of music therapy and verbal relaxation on chemotherapyinduced anxiety. Journal of Clinical Nursing. 2011. Available from: https://pubmed.ncbi.nlm.nih.gov/21902742/

[22] Warth M, Keßler J, Hillecke TK, et al. Music Therapy in Palliative care. 2015. Available from: https://pubmed.ncbi.nlm.nih.go $\mathrm{v} / 26806566 /$

[23] Gutgsell K. A Music Therapist Shares Stories of Patients with Cancer. Cancers. 2016; 8(11): 104. PMid:27854273 https://doi.org/10 .3390/cancers8110104 